ENTREPRENEURSHIP AND SUSTAINABILITY ISSUES

ISSN 2345-0282 (online) http://jssidoi.org/jesi/

2020 Volume 7 Number 4 (June)

http://doi.org/10.9770/jesi.2020.7.4(45)
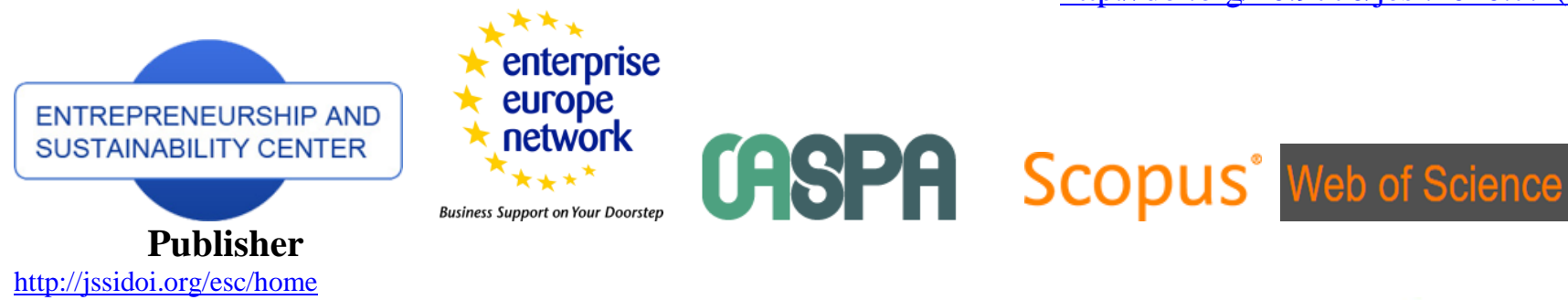

$\underline{\text { http://jssidoi.org/esc/home }}$

\title{
TOURISM MANAGEMENT IN BORDER DESTINATIONS: REGIONAL ASPECTS OF SUSTAINABLE DEVELOPMENT OF PROTECTED NATURAL AREAS
}

\author{
Alexandr N. Dunets ${ }^{1 *}$, Nataliia A. Gerasymchuk ${ }^{2}$, Vladimir M. Kurikov ${ }^{3}$, \\ Elena E. Noeva ${ }^{4}$, Mariya Y. Kuznetsova ${ }^{5}$, Rustem A. Shichiyakh ${ }^{6}$ \\ ${ }^{1}$ Altai State University, Lenin Ave, 61, 656049, Barnaul, Russian Federation \\ ${ }^{2}$ Rzeszow University of Technology (Politechnika Rzeszowska), al. Powstancow Warszawy, 12, 35-959, Rzeszow, Poland \\ ${ }^{3}$ Yugra State University, Chekhov street, 16, 628012, Khanty-Mansiysk, Russia \\ ${ }^{4}$ North-Eastern Federal University named after M.K. Ammosov (NEFU), Belinskogo Street, 58, 677000, Yakutsk, Russia \\ ${ }^{5}$ Sechenov First Moscow State Medical University, Trubetskaya street, 8-2, 119991, Moscow, Russia \\ ${ }^{6}$ Kuban State Agrarian University named after I.T. Trubilin, Kalinina street, 13, 350044, Krasnodar, Russia
}

E-mails: ${ }^{I^{*}}$ dunets@mail.ru (Corresponding author)

Received 14 August 2019; accepted 20 March 2020; published 30 June 2020

\begin{abstract}
Mountain regions are natural boundaries and, in most cases, they are characterized by a fragmentation of ethnic composition and are places of contact between countries. Currently, national parks and reserves have been created in the border mountain areas. Touching within the state border, they require special attention for their sustainable development. In Central Asia, one of these regions is the Altai. In these areas, some specially protected natural territories were created as part of the World Heritage reserve, to preserve the nature, culture, traditions, and archeology of the four states. Studies of this area have revealed possible options for the development of cross-border tourism. This requires a coordinated policy on tourism management in cross-border destinations and the development of cross-border tourism. The results of the study made it possible to carry out functional zoning of the cross-border territory, develop a network of tourist routes and make recommendations on the creation of border crossings, as well as on the development of tourist infrastructure.
\end{abstract}

Keywords: cross-border region; Altai mountains; tourism; protected natural areas

Reference to this paper should be made as follows: Dunets, A. N., Gerasymchuk, N. A., Kurikov, V. M., Noeva, E. E., Kuznetsova, M. Y., Shichiyakh, R. A. (2020). Tourism management in border destinations: regional aspects of sustainable development of protected natural areas. Entrepreneurship and Sustainability Issues, 7(4), 3253-3268. http://doi.org/10.9770/jesi.2020.7.4(45)

JEL Classifications: Z32, L83, Q01

Additional disciplines ecology and environment; geography 


\section{ENTREPRENEURSHIP AND SUSTAINABILITY ISSUES}

ISSN 2345-0282 (online) http://jssidoi.org/jesi/

2020 Volume 7 Number 4 (June)

http://doi.org/10.9770/jesi.2020.7.4(45)

\section{Introduction}

Many cross-border destinations are of interest to tourists. This is caused by an opportunity of closer contact with the territory of a neighboring state or of crossing the border and visiting a neighboring country. Tourism management in the border areas should be adaptive to the natural and socio-economic characteristics of a territory. Tourism development in protected natural areas is associated with territorial planning and allocation of functional zones, as well as identification of their recreational capacity.

Nature conservation and tourism development are closely interconnected, and therefore, research in this field may be of priority importance for border areas. However, various kinds of contradictions arise in the mountain regions. Complex terrain and inaccessibility lead to the need to build an infrastructure of a particular type. There are some contradictions of environmental and economic interests. Conflicts may be associated with a change in the traditional activities of the local population during the tourist season (Suprunenko, 2003; Singgalen et al. 2019).

Along with the tourist attractiveness of the mountain regions, they are distinguished by the increased vulnerability of the natural and socio-cultural environment. Management of tourism development in the border areas is of interest to neighboring states (Korableva et al., 2019).

The Altai mountain region is located in the center of Eurasia, within the borders of the four states: Russia, Kazakhstan, China, and Mongolia. In the alpine zone of the border area, there are protected natural areas. The presence of state borders in the region, on the one hand, separates, and on the other, connects countries in the Altai region, establishing the prospects for interaction in nature conservation and tourism development.

\section{Literature review}

Mountain regions are natural boundaries and, in most cases, they are characterized by a fragmentation of ethnic composition and are places of contact between countries. Borders can be barriers or areas of cooperation (Badenkov, 2002). The mountainous regions of the world are characterized by a significant variety of conditions and factors that ensure the opportunities for cooperation in border areas. The single natural-historical space of the border territories contributes to the interaction of nations.

A special type of space is created along state borders, characterized by different intensities of interaction between countries, including the intensity of cross-border flows. The border space is a zone characterized by the length, width, and density of objects (Kolosov, 2010).

Mountain ranges play a leading role in the territorial structure of tourism. They are natural boundaries and affect the fact that in a relatively small area, the climate, water resources (Yemelyanov et al., 2018), flora and fauna, and also local ethnic groups with a particular culture can vary significantly.

The desire to preserve the common natural and cultural heritage in a mountain region serves as a motive for many border territories of different countries to develop cross-border regional cooperation. The development of formal and informal ties between residents of border regions helps to strengthen mutual trust. Cross-border regionalism is caused by the desire to develop new effective forms of collective activity, to promote ethno-cultural interaction and economic development (Polyakova et al., 2019; Sharafutdinov et al., 2019).

Geographical cross-border entities are of particular importance in international cooperation. This is considered by the example of the Altai-Sayan region, and protected areas were identified that contribute to the conservation of biodiversity and the development of ecotourism (Dunets et al., 2019). 


\section{ENTREPRENEURSHIP AND SUSTAINABILITY ISSUES}

ISSN 2345-0282 (online) http://jssidoi.org/jesi/

2020 Volume 7 Number 4 (June)

http://doi.org/10.9770/jesi.2020.7.4(45)

The idea of cross-border cooperation in the field of environmental protection in a region was first voiced in 1998 at a conference on the development strategy of Central Asia in Urumqi. A Protocol of Intent was signed to develop an international Convention on the sustainable development of the Altai Mountain Region (Badenkov, 2017). In order to preserve the unique natural complex and historical and cultural heritage in the Altai region, a number of major international projects have been implemented. Since 1997, on the initiative of the World Wide Fund for Nature (WWF), the project "Ensuring the Long-Term Conservation of Biodiversity of the Altai-Sayan Ecoregion (Global 200)" has been implemented. In 2001, a project for the development of protected natural areas in the region was prepared and a landscape map was created (Samoilova, 2000).

Important projects aimed at the development of protected natural territories of the border areas of the Altai were: the UN Development Programs UNDP/Capacity 21 "Development and Implementation of Local Sustainable Development Strategies in the Republic of Altai, Russia" (2001); UNDP/GEF "National Strategy and Action Plan for the Conservation of Biodiversity" (Kazakhstan, 2001); UNDP / GEF "Conservation of Biological Diversity in the Altai-Sayan Ecoregion" (Russia, Kazakhstan, Mongolia, China, 2001). UNDP/GEF "Biodiversity Conservation in the Russian Part of the Altai-Sayan Ecoregion" has contributed to the development of protected areas and ecotourism in the region. In 2012, WWF released the Altai-Sayan Ecoregion Conservation Strategy, which analyzes the situation, identifies strategic priorities for the protection and cooperation with the local population (Altai-Sayan Ecoregion ..., 2012).

In 2017, UNESCO officially approved the creation of Asia's first Big Altai transboundary biosphere reserve. It includes the Katun Reserve (Russia) and Katon-Karagay National Park (Kazakhstan). A plan of joint scientific and educational activities has been identified (Yashina, Krykbaeva, 2017). Based on the principles of the Seville Strategy for Biosphere Reserves, the main tasks are: to preserve the biological and landscape diversity, as well as the cultural values of the territory, to promote the sustainable development of local communities, to provide scientific and technical support for the conservation and sustainable development of the territory. During the development of the management plan for the cross-border territory, the main existing and potential threats that affect the biodiversity and ecosystems of the protected area were identified. In the Russian part of the Altai, there were three options for creating a cross-border biosphere territory. They suggested the inclusion of Russian units besides the Katun Reserve, a number of protected natural areas of the Kosh-Agachsky District of Republic of Altai and the Tigirek Reserve of the Altai Territory (Vinokurov, Krasnoyarova, Surazakova, 2006). However, the creation of a cross-border territory is a complex multi-year process that requires the political will and investment for development.

\section{Methods}

A study of the organization of tourism in the border territories of neighboring countries can be based on a regional research approach. For this, it is necessary to distinguish a cross-border territory as an object of study and consider the geographical position and administrative-territorial division of the studied territory. The sequence of studying the region involves an analysis of natural features and social conditions for the development of tourism. It is also important to analyze the social characteristics affecting tourism in the region (displacement of population, urbanization, ethnic structure, language, religion, traditions, etc.). An analysis of the main economic indicators of tourism should be carried out in accordance with the availability of infrastructure to preserve the natural environment, as well as the seasonality of tourist flows. This will identify the main problems and offer prospects for sustainable tourism development in the region. Such a study will allow for territorial planning, which is an important element of strategic management.

Territorial planning is aimed at identifying the spatial structure of actions and land use, which is necessary for rational nature management based on the region's natural resources, prerequisites, and limitations of tourism development (Hall, 2008). Territory planning has as its goal the preservation of the natural resource potential of 


\section{ENTREPRENEURSHIP AND SUSTAINABILITY ISSUES}

ISSN 2345-0282 (online) http://jssidoi.org/jesi/

2020 Volume 7 Number 4 (June)

http://doi.org/10.9770/jesi.2020.7.4(45)

the territory, the formation of a comfortable environment for human life, safe and convenient settlement, costeffective and environmentally sound distribution of economic activity. Suprunenko (2003) notes that mountain regions require special approaches to territorial tourism planning as they are characterized by reduced resistance of natural geosystems to anthropogenic stresses.

Management of tourism development can be based on the concept of a "polarized landscape" by Rodoman (2002), which proposes a model for the balanced development of urbanization poles and protected areas, while preserving the natural environment provides for the arrangement of recreational areas and tourist routes.

As an expression of the real planning embodiment of this concept in territorial design, the theory of the natural frame is used (Vladimirov, 1986). Kolbovsky (2006), studying the development of ecotourism, proposes to use the concept of ecological frame. The frame is a grid of numerous intersecting linear elements, in places at the intersections of which nodes are formed. The nodes of the frame are responsible for the implementation of the environment-forming function and are represented by the upper reaches of the largest rivers (upper landscape belts), lake systems, the largest forests, etc. (Stoyashcheva, 2007). Transit corridors are called continuous or partially discontinuous almost linear structures, the natural properties of which differ significantly from the surrounding environment. Ecological corridors are considered an important factor providing species migration (Kolbovsky, 2008).

Garms, Sukhova, Khromykh (2014) highlighted the zoning of the cross-border territory of the Altai. For this purpose, the favorable conditions for tourism of the relief, climate, water resources and vegetation were studied in the border administrative districts.

The territorial organization of tourism activities should be based on the development of concepts and models for the optimal localization of tourist flow and the identification of the territorial planning structures of the region. It includes zones with different security arrangements and tourist development. For this, it is necessary to carry out functional zoning as an obligatory action when doing the territorial planning of protected areas. The basic principles of functional zoning are considered in numerous sources and there is a study on the generalization of the available experience for recreational areas (Mironenko, Bochvarova, 1986). Functional zoning is aimed at preserving valuable territories and ensuring the maximum compliance of tourist resources in accordance with the law.

Chernova (2018), from the point of view of recreational zoning, suggests combining the natural complexes of the cross-border Altai region into recreational and nature protection, economic and recreational, nature protection and recreational, recreational and economic, economic and nature protection zones.

In the border regions of the Altai, one can distinguish such functional zones as the resource zone, including territories and water areas, the zone of residence of the local population and temporary service staff (housing, a number of tourism and recreation facilities, services, etc.), the zone with economic functions (agriculture, industry, and transport), the protected zone, the zone of tourist accommodation facilities, the intensive use zone for serving tourists, and the tourist routes. However, within the protected natural areas, it is necessary first of all to distinguish a nuclear protection zone and a buffer zone. In these territories, a special visiting arrangement and a limited number of tourists are provided.

In the territory of the Big Altai cross-border biosphere reserve, several functional zones have been identified: a reserved core to provide long-term protection of biological and landscape diversity; a buffer zone created to prevent and minimize the negative impact of anthropogenic activities on protected areas; a cooperation zone in which activities are aimed at promoting the sustainable development of local communities (Yashina, Krykbaeva, 2017). The earlier work on landscape planning of the Ukok Plateau made it possible to allocate territories for the 


\section{ENTREPRENEURSHIP AND SUSTAINABILITY ISSUES}

ISSN 2345-0282 (online) http://jssidoi.org/jesi/

2020 Volume 7 Number 4 (June)

http://doi.org/10.9770/jesi.2020.7.4(45)

purposes of "preferential preservation of the current state", "abandonment of use" and "preservation of existing extensive use" (Babin et al., 2011).

The tourist route is the basis of the spatial organization of tourist activities. The functional purpose of the route, due to the combination of individual actions and attractions, determines the type of tourism. Therefore, in the territorial organization of tourism, the basis of ecotourism development of protected natural areas may be a network of routes that optimally ensures the availability of tourist facilities.

Thus, tourism research in protected areas includes regional studies of the natural basis and development of a territory, and management should include the development of an action plan based on functional zoning as a necessary part of planning the territorial development of a cross-border area of the Altai region.

\section{Results}

The geographical position of the border protected natural areas of the Altai is ambiguous. The Russian part of the region is remote from the main centers of tourist suppliers. To the north of the Altai, there is the main settlement strip in Asian Russia. Therefore, the Altai Mountains for tourists of Siberia are the most accessible region for recreation. In the west, the region is adjacent to the territories of Central Asia. The southwest Altai is interesting for both domestic and international tourists. The presence of the sanatorium "Rakhmanovsky Creek" contributes to the development of health tourism. This region is traditionally popular for hiking and exploring the life of Old Believers. The Altai District of Xinjiang Uygur Autonomous Region is located on the periphery of China and, basically, is now attractive for domestic (Chinese) tourism. There is the only area of Siberian taiga in China, the territory is very popular, and Kanas National Park attracts about 2 million tourists annually.

The intercontinental position of the Altai determines the intersection of the geopolitical interests of countries, including the protection of the natural and cultural-historical heritage, as well as the development of tourism. The presence of state borders in the Altai has now led to significant differences in the structure and types of environmental management. However, similar features are characteristic of border regions: a certain range of types of economic activity, a low level of development, ethnocultural similarity, etc.

The problems of tourism development in a cross-border region are largely associated with the difficulties of visiting border areas, poor development of border crossings and visa formalities. Many tourist-friendly objects are located in the border zone (the Ukok Plateau, the Belukha Mountain, etc.). Tourists are interested to visit two or more countries at once when traveling to the highlands of the Altai.

Specially protected natural territories have been created in the border areas of the Altai. The basis of territorial nature conservation is protected areas of the following categories: reserves, national parks, and wildlife sanctuaries. Among them are: Katun and Markakol Reserves; Saylyugem, Sayluchem Nuru, Katon-Karagay, Kanas, and Tavan-Bogd national parks. In 1998, five sites of the Republic of Altai were included in the register of the UNESCO World Heritage Sites. These territories are called the Altai Golden Mountains (figure 1). 


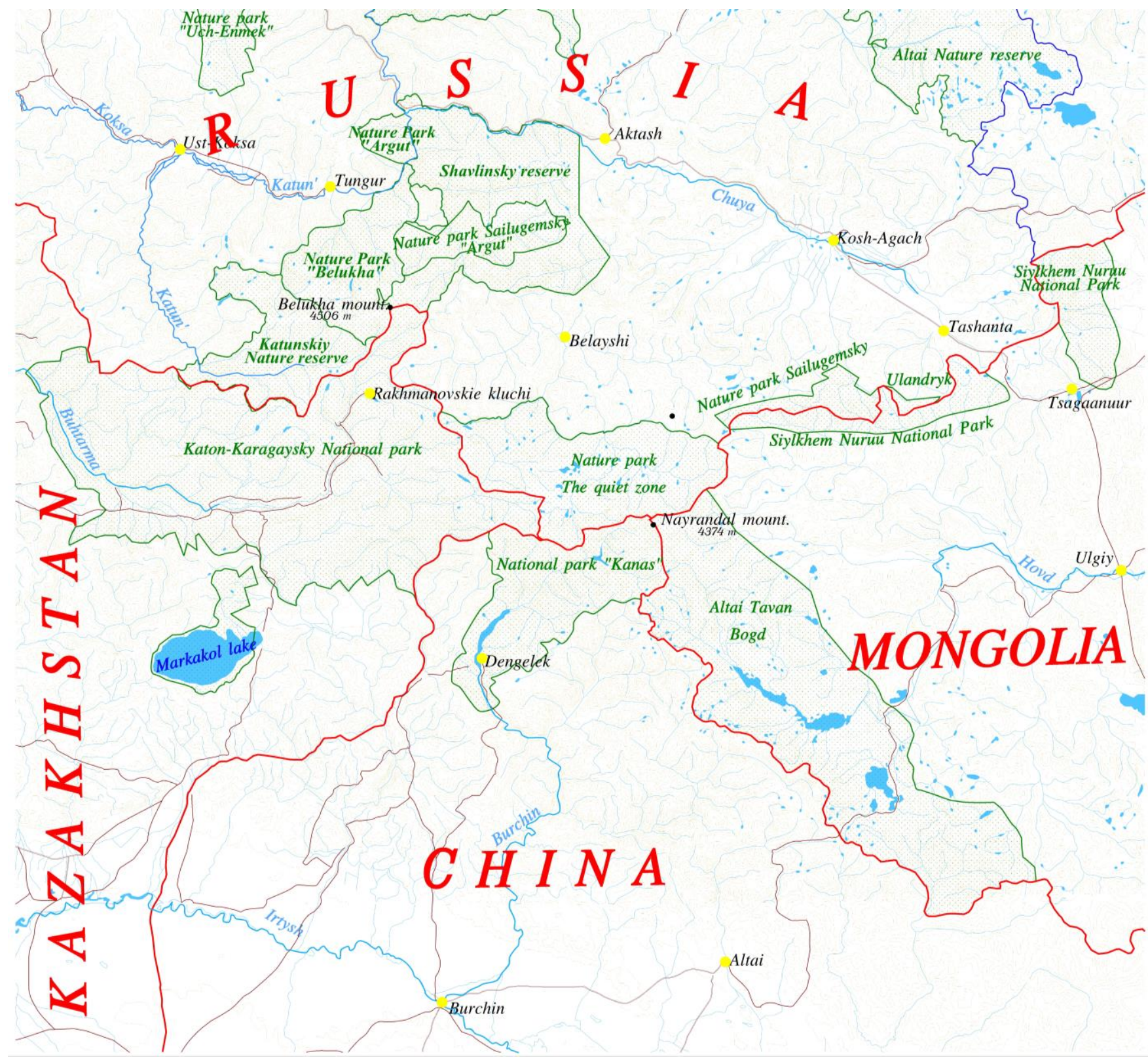

Fig. 1. Protected areas of the cross-border Altai region Source: authors' research

However, the increase in the number of protected areas, including those with a strict security arrangement, does not bring full satisfaction to both local residents and tourists. An important task is the functional zoning of the protected natural territories of the region and the management of the procedure of tourist visiting these territories and their buffer zones. The most successful work can be noted in Kanas National Park. Here, the allocation of protection nuclei is combined with the development of traditional farming in villages and the development of hiking trails. Most hotels are located outside the national park. Sustainable development in the region is impossible without improving the quality of life of the population. Therefore, it is necessary to combine nature protection with the development of the traditional economy and tourism. 


\section{ENTREPRENEURSHIP AND SUSTAINABILITY ISSUES}

ISSN 2345-0282 (online) http://jssidoi.org/jesi/

2020 Volume 7 Number 4 (June)

http://doi.org/10.9770/jesi.2020.7.4(45)

The border has an important transit function. In most cases, tourists do not stay at the border; having passed the necessary control, they continue to follow the main destination. However, the state border may be an object of special interest for tourists, and the border territory can act as a tourist destination (Aleksandrova, 2009). For example, between Russia and Mongolia, at the border checkpoint of Tashant, the neutral strip occupies more than $20 \mathrm{~km}$. For many tourists, the very stay in this strip is of interest, since there is no anthropogenic impact. For example, marmot-tarbagans (Marmota sibirica) have a large population there and are not particularly afraid of passing cars. The use of border areas as tourist destinations is based on a variety of landscapes and the presence of unique objects attractive for tourism.

The reliefs of the border areas of the Altai are characterized by mountain ranges, elevated hilly plateaus, and intermountain basins. The higher the mountains, the more they are popular among tourists. The relief most attractive for tourism is characterized by an absolute height of more than $1,500 \mathrm{~m}$, a slope steepness of $30-35^{\circ}$, and a depth of vertical dissection of more than $800 \mathrm{~m}$ (Bredikhin, 2004). In the southwest of the cross-border zone in the Markakol Reserve and Katon-Karagay National Park, the depth of the relief is from 300 to $600 \mathrm{~m}$. On the Katun Ridge in its highland part, the relief is 1,000-1,200 m or more (Garms et al., 2014). On a large territory of the Ukok Plateau at a height of about $2,000 \mathrm{~m}$, there are many ancient moraine deposits. The relief of the highlands is distinguished by contrast, aesthetics, attractive landscapes, but is not suitable for mass tourism due to the severity of the bio-climate, low atmospheric pressure and the inaccessibility of tourist activities in the highlands. Most territories of the cross-border Altai have a favorable relief for the development of tourism.

The climate of the region has pronounced continental features: cold long winters and short warm summers. Together with the relief, the climate has a decisive natural influence on the development of tourist and recreational activities. In winter, an Asian anticyclone is located here, which gives a long cold winter with pronounced temperature inversions. The temperature at the surface of the earth in the intermountain basins is lower than on the mountain slopes. The relief affects the formation of local winds (hair dryers, slope, valley, glacial and other winds).

The water components of the natural complex constitute an important part of the natural resources of the crossborder region. Many lakes are picturesque and attract many tourists. A large center of glaciation is the TavanBogdo-Ula mountain junction, where the largest valley glaciers are located. Other large massifs of glaciers are the Belukha glaciers. There are small glaciers and firn fields in a number of other mountain ranges. The lakes are also of interest; the largest one is the Markakol, Kanas. There are many lakes on the Katun Ridge and in the Mongolian Altai. A denser river network is in the Russian and Kazakhstani parts of the Altai. In forest and nivalglacial landscapes, it is possible to organize hiking, skiing, mountain trails, as well as climbing. The combination of glaciers and peaks with a height of more than 3,000 m creates excellent conditions for organizing mountain trips. Interesting water features for tourists are waterfalls. The largest of them is the Kokkol, its height being $80 \mathrm{~m}$ (the Katon-Karagay National Park). The Rassypnaya waterfall (the Republic of Altai), with a height of $35 \mathrm{~m}$, is very famous.

On the leveled surfaces of valleys, hollows, and plateaus, the landscape is mainly steppe, and in the mountain taiga zone up to an altitude of 2,000-2,200 m, there are larch forests. In more humid areas, dark coniferous taiga of cedar, fir, and spruce dominates. In the lower zone of the highlands, thickets of undersized shrubs and subalpine meadows dominate, which are higher replaced by alpine meadows with an abundance of herbaceous plants. For scientific tourism, such factors as endemic species and the presence of rare plant communities are important. This enhances the cognitive and scientific value of the territory, represents a resource base for ecological tourism, but also imposes environmental restrictions. Landscapes of the territory are low-mountain, mid-mountain, and high-mountain (Fig. 2). The fauna of the cross-border territory is also very rich and diverse. The region is located at the junction of the Central Asian and Siberian faunistic provinces. In the southern, Mongolian part of the region, steppe and semi-desert species prevail: dzeren, marmot-tarbagan, birds of prey. 


\section{ENTREPRENEURSHIP AND SUSTAINABILITY ISSUES}

ISSN 2345-0282 (online) http://jssidoi.org/jesi/

Argali (mountain sheep), mountain goat, snow leopard, golden eagle, and ular are found only in the highlands. In the highlands, yaks and camels are bred.

Currently, there is a revival of old traditions associated with pagan customs, Shamanism, Islam, Buddhism, and Lamaism. The culture of indigenous peoples is based on the traditions of pastoral tribes leading a nomadic lifestyle (nomadic animal husbandry). Part of the population still lives in plagues, yurts, and other traditional structures. Many ethnic groups still retain the traditional way of life and nature management.

The Bayan-Ölgii Aimag of Mongolia is mainly populated by Kazakhs (about 90\%), Urikhai people (7.2\%). The Kosh-Agachsky District of Russia is also populated predominantly with Kazakhs. In the Altai administrative district of China, the most numerous are Kazakhs, Chinese, Uighurs, Dungans, Oirat Mongols, etc. The Altai is famous for its abundance of archaeological sites. On the Ukok Plateau, there are mounds of the Pazaryk culture, including the burial place of "the Altai Princess". In recent years, many amazing archaeological finds have been made and the cross-border Altai can be a place of archaeological tourism. Traditional nature management and life features of the local population significantly increase the attractiveness of the territories (figure 2, table 1).

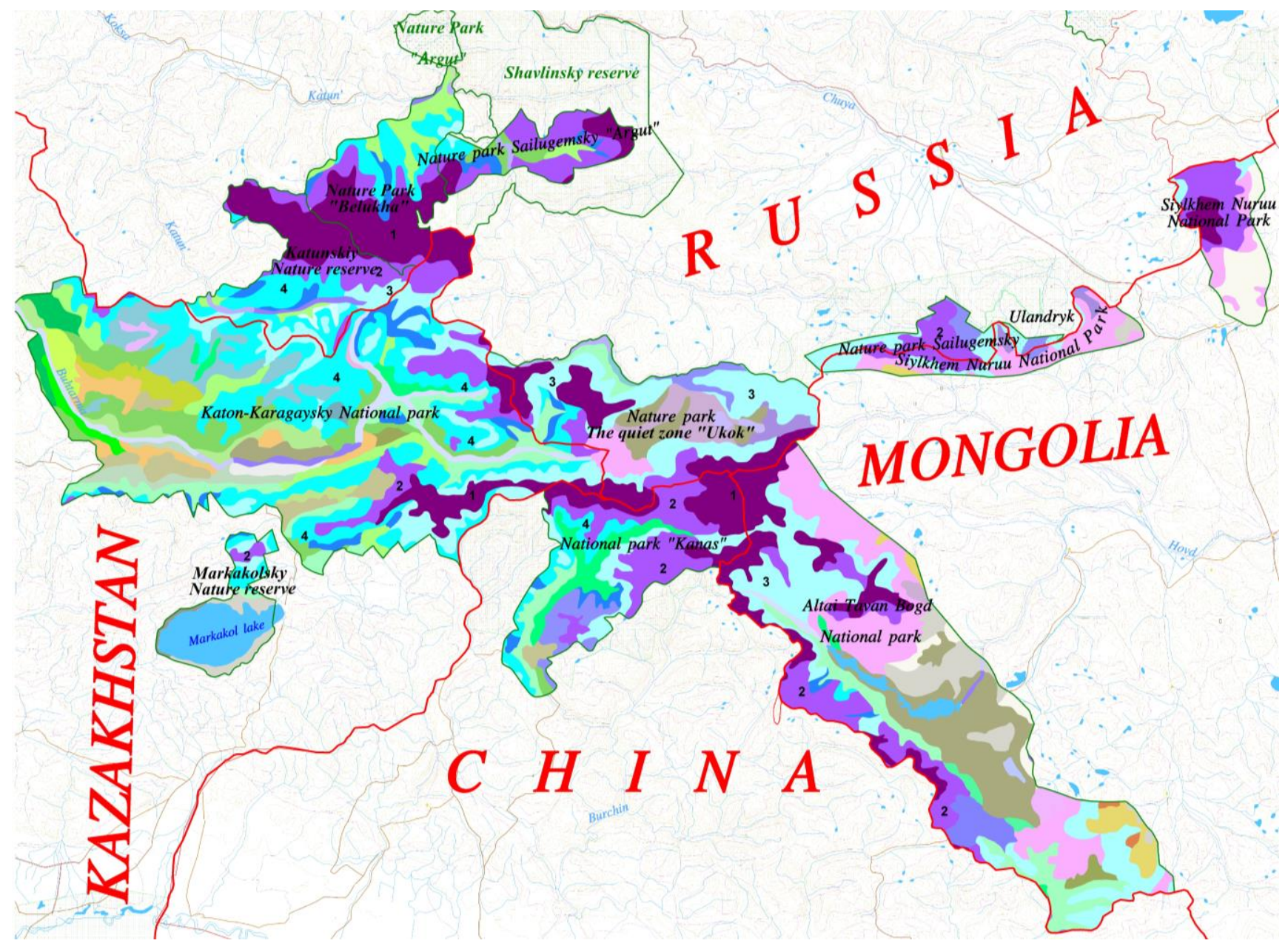

Fig. 2. Landscape map and protected areas of the cross-border Altai Source: authors' research 


\section{ENTREPRENEURSHIP AND SUSTAINABILITY ISSUES}

ISSN 2345-0282 (online) http://jssidoi.org/jesi/

2020 Volume 7 Number 4 (June)

http://doi.org/10.9770/jesi.2020.7.4(45)

Table 1. Characteristic landscape structure of protected natural areas of the cross-border Altai

\begin{tabular}{|c|c|c|c|}
\hline № & $\begin{array}{l}\text { Name protected natural } \\
\text { areas and area in sq.m. }\end{array}$ & $\begin{array}{l}\text { The number of types of } \\
\text { landscapes / numbers of the } \\
\text { main types (percentage of } \\
\text { the total area) }\end{array}$ & $\begin{array}{c}\text { Numbers and names of the main types of core } \\
\text { landscapes protected natural areas }\end{array}$ \\
\hline 1. & $\begin{array}{l}\text { Katunskiy Nature reserve, } \\
3275342\end{array}$ & $9 / 1(28 \%) ; 4(26 \%)$ & \multirow{11}{*}{$\begin{array}{l}\text { High-mountainous } \\
\text { Exarational erosion denudational } \\
\text { Nival-glasial }\end{array}$} \\
\hline 2. & $\begin{array}{l}\text { Nature Park "Belukha", } \\
3037360\end{array}$ & $10 / 1(40 \%)$ & \\
\hline 3. & $\begin{array}{l}\text { Nature park The quiet } \\
\text { zone "Ukok", } 5758661\end{array}$ & $15 / 3(33 \%) ; 1(20 \%)$ & \\
\hline 4. & $\begin{array}{l}\text { Nature park Sailugemsky, } \\
900861\end{array}$ & $3 / 2(50 \%)$ & \\
\hline & Ulandryk, 127578 & $3 /(60 \%)$ & \\
\hline & Argut, 1761858 & $6 / 2(49 \%) ; 1(18 \%)$ & \\
\hline 5. & $\begin{array}{l}\text { Katon-Karagaysky } \\
\text { National park, } 19413396\end{array}$ & $\begin{array}{l}30 \text { / } 4(23 \%) ; 3(9 \%) \\
2(6 \%) ; 1(5,5 \%)\end{array}$ & \\
\hline 6. & $\begin{array}{l}\text { Markakolsky Nature } \\
\text { reserve, } 1719919\end{array}$ & $\begin{array}{c}8 \text { / } 4 \text { (10\%); } 3(7 \%) ; \\
2(4 \%) \\
\text { Площадь озера 57\% }\end{array}$ & \\
\hline 7. & $\begin{array}{l}\text { National park "Hanasi", } \\
4988247\end{array}$ & $10 / 2(27 \%) ; 1(18 \%)$ & \\
\hline 8. & $\begin{array}{l}\text { Altai Tavan Bogd } \\
\text { National park, } 1412125 \\
\end{array}$ & $\begin{array}{c}25 / 3(18 \%) ; 1(10 \%) ; \\
2(9 \%)\end{array}$ & \\
\hline 9. & $\begin{array}{l}\text { Siylkhem Nuruu National } \\
\text { Park (cluster 1), } \\
1556426 \\
\text { Siylkhem Nuruu National } \\
\text { Park (cluster 2), } 1873 \\
605\end{array}$ & $5 / 2(43 \%) ; 1(11 \%)$ & \\
\hline
\end{tabular}

Source: Samoilova, 2000

Landscapes of glacial-nival highlands with tundra vegetation are highly significant; however, the bioclimatic conditions of these territories are extreme for visiting. The landscapes of mountain taiga with larch forests, alpine meadows, mountain tundra with meadows and shrub tundra are attractive for tourism. Tundra-steppe landscapes are not of particular interest for visiting.

In order to develop cooperation in the border regions of the Altai, coordination of functional zoning is necessary, taking into account the value of landscapes for protection and the possibility of tourist use. Evstropyeva (2009) notes that the associated tourist development of the border areas leads to the "blurring" of the borders for tourists and the increase in the effects of interaction in the cultural, social, economic and environmental spheres. Active cooperation between Altai countries in connection with the implementation of joint tourism projects not only opens up the opportunities for increasing foreign tourist flows to the countries of the region but also helps to expand similar ties with other neighboring states.

An effective way to overcome administrative boundaries is to organize cross-border protected natural areas. Interstate borders are more surmountable, since states are territories of administrative division of a world level and agreements are reached at official negotiations between countries. This relates to the contradiction of the noneconomic ideology of creating nature reserves at the global level (Kalikhman, 2007). The goal of creating cross- 
border protected natural areas is to preserve the unique ecosystem of the Altai highlands and glaciers, and possibly to obtain the status of a World Natural Heritage. To manage them, a "polarization of ecosystems" is necessary with separation into areas of permissible tourist use and conservation of natural resources. It is also important to develop the local traditional economy. For this, the authors have proposed a scheme of functional zones (figure 3).

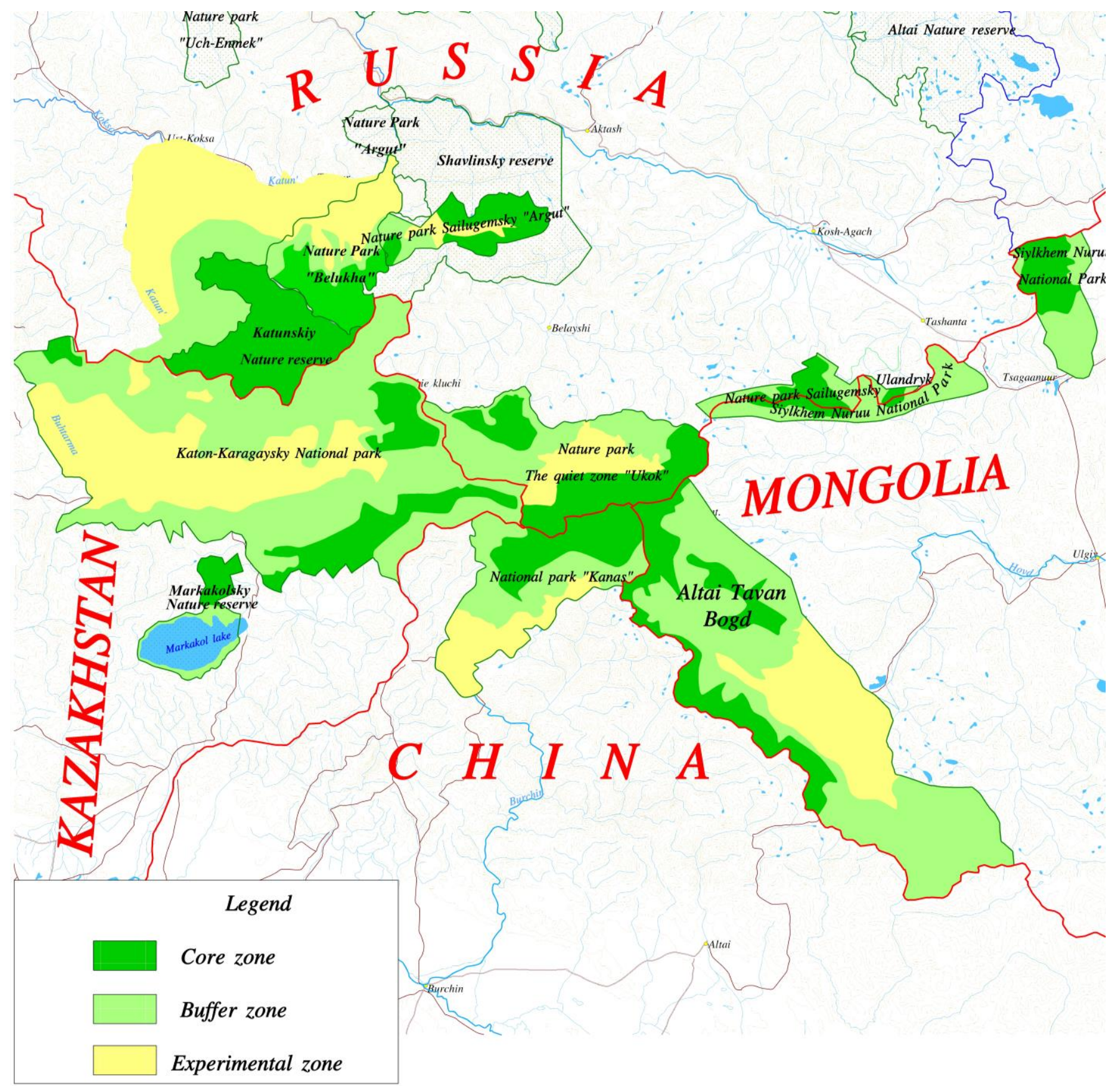

Fig. 3. Functional zoning of protected natural territories of the cross-border Altai Source: authors' research 


\section{ENTREPRENEURSHIP AND SUSTAINABILITY ISSUES}

ISSN 2345-0282 (online) http://jssidoi.org/jesi/

2020 Volume 7 Number 4 (June)

http://doi.org/10.9770/jesi.2020.7.4(45)

Functional zoning shows the priorities in organizing activities in the territory. In order to manage the development of tourism in the border areas, it is necessary to form a frame of ecotourism. The frame contributes to the formation of a single cross-border region. The analysis has shown that is the linear planning type of tourist zones, formed on the basis of natural dominants, intermountain basins, along the banks of water bodies, in river valleys, is the most widespread in the Altai. However, the presence of significant tourist sites, primarily lakes, contributes to the formation of tourism centers. The local population to some degree influences the ecological frame. For example, sacred places for residents are protected from the environmental, cultural, historical or spiritual points of view. An example would be an active public campaign against the construction of the Russia-China highway through the Ukok Plateau. From an environmental perspective, the issue is also not so straightforward. On the one hand, the construction of direct infrastructure is possible only with an obligatory intersection of at least a World Natural Heritage Site - the Ukok Quiet Zone, although there are some examples in the world of intersections of UNESCO World Heritage Sites by roads (Krasnoyarova, 2010).

In the conditions of a cross-border mountain region, it is advisable to design routes including territories of two or more states. For example, the main cross-border route is the Altai Golden Mountains. This route brings together many existing and planned tourist facilities located in four states. The idea of the route is combining objects with a network of roads and engineering infrastructure (Pomorov, 2008). However, the existing road network does not contribute to the development of the route. There is a need for the formation of new transport corridors primarily between the Republic of Altai and East Kazakhstan Region. The construction of the road from the point of the confluence of the Chuya River into the Katun to the settlement of Tyungur will significantly increase the flow of tourists to Belukha Natural Park and the Katun Nature Reserve. Tourist flows will not only be dispersed along the network of routes but will also concentrate in the ecotourism centers. Basically, they will probably be small and tend to the main roads, where several routes converge.

For cross-border cooperation in the Altai, it is necessary to create new border crossings, possibly working only in the warm season. One of them is advisable to be created in the upper Katun. This will provide a real link to the cross-border protected natural area - the Katun Reserve and Katon-Karagay National Park. This will contribute to an increase in the number of tourists in the border areas and, according to experts, after the opening of the crossing, within 1-2 years the number of cross-border tourists will be 10-15 thousand at the initial stage. The tourist flow to Katon-Karagay Region of Kazakhstan will naturally enter the Russian part. In addition, circular tours will become possible, starting in the Russian Altai through Kazakhstan and back to Russia. Such crossborder routes will be of particular interest for third parties (for example, Chinese tourists). Fig. 4 presents the offers on the development of the ecotourism frame of the cross-border Altai. The implementation of these offers will change the tourist and geographical position of the region. A peripheral border area may become a transit for tourists wishing to visit the Altai (figure 4). 


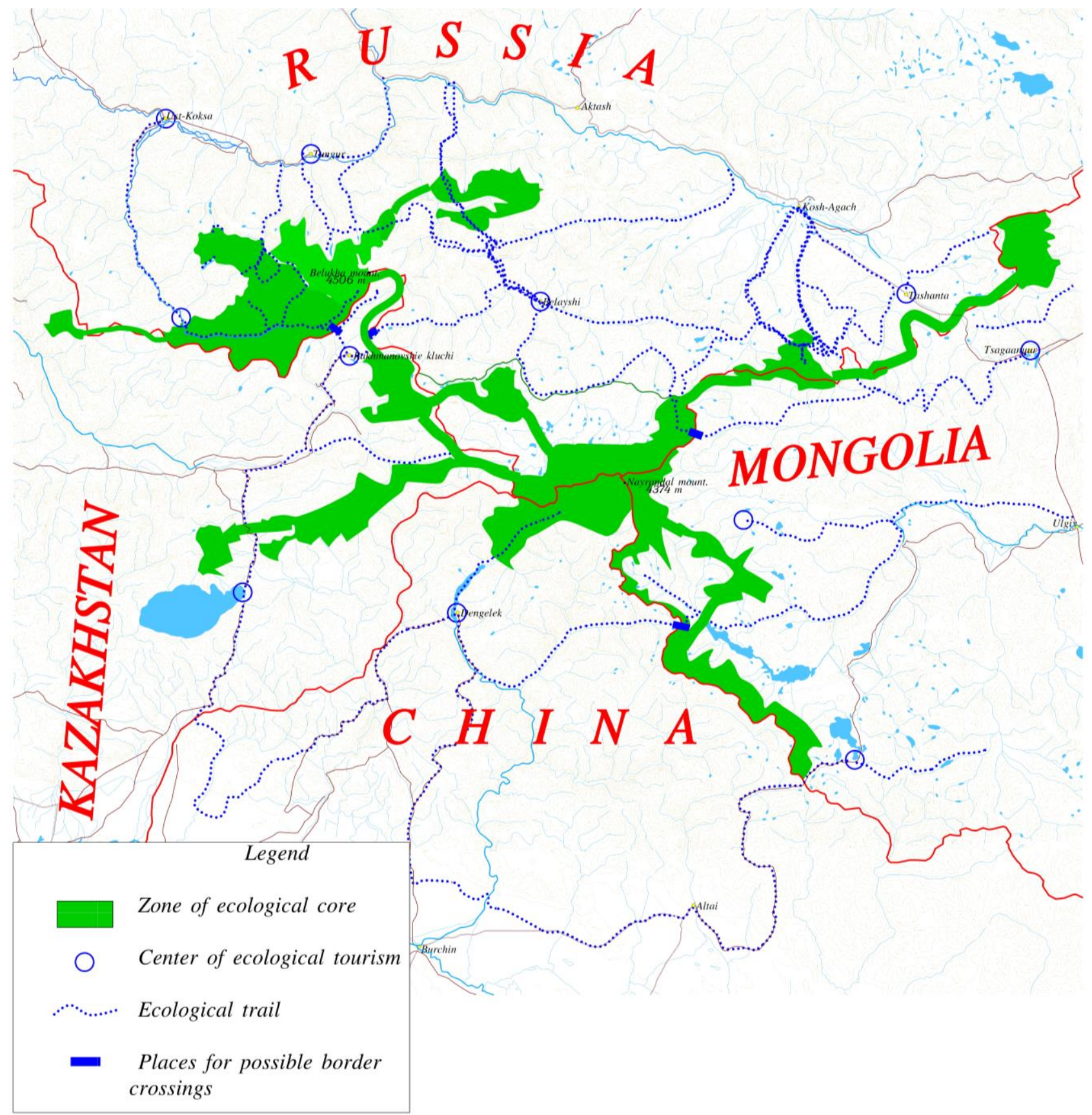

Fig. 4. Promising ecotourism frame of the cross-border Altai Source: authors' research

\section{Discussion}

The border parts of the Altai are distinguished by an increased relevance of ecological tourism, due to the presence of a large number of protected natural areas. Consideration of aspects of the territorial administration of protected areas should include the expansion of the area of protection and research of natural heritage, as well as the construction of trails in the natural territories as the basis of the visiting infrastructure in accordance with the principles of ecotourism. 


\section{ENTREPRENEURSHIP AND SUSTAINABILITY ISSUES}

ISSN 2345-0282 (online) http://jssidoi.org/jesi/

2020 Volume 7 Number 4 (June)

http://doi.org/10.9770/jesi.2020.7.4(45)

Preservation of the natural and socio-cultural environment of the mountain region is associated with the planning of adequate types of tourism organization and identification of the optimal capacity of tourist flows. For mountainous areas, it is especially important that the higher the ecological value of objects, the less humaninduced interference should be. The deeper the tourist center is embedded in the natural landscape, the smaller its size should be.

The mechanism for the development of cross-border tourism cooperation and tourism resources of the border areas of the Altai has not yet been developed. Therefore, it is important to create a coordination council for tourism, which may include administrative entities of the Altai countries, within the framework of which it could be possible to manage tourism activities in the region. Such work already has some initial results in connection with the activity of the International Coordination Council "Our Common Home - Altai".

Important principles for the development of border areas include: taking into account landscape elements in the architectural style of tourist zones; priority construction of year-round facilities; construction of tourist camps for a one-day stay of tourists on mountain routes. When planning tourism in protected areas, it is advisable to design not individual buildings, structures, and complexes, but the landscape as a whole, preserving its original characteristics and appearance; to integrate architecture and nature leaving the priority for the latter; to form buildings, structures, and complexes as "extensions" of the natural landscape (Pomorov, 2008). It is necessary to ensure low-rise construction of accommodation facilities and other tourist infrastructure. However, such territory planning should not affect the decline in the quality of service. Currently, consumers of travel services increasingly prefer comfortable accommodation, equipped territory and hiking trails.

The organization of the tourism structure of a cross-border region is associated with the implementation of specific tourism projects on the basis of the principles of sustainable tourism development and interstate cooperation. First of all, such projects are: ecotourism development of protected natural areas, cross-border routes, tourist infrastructure, information network (Altai Transboundary website www.altaiinter.info, etc.).

Tourism cooperation between administrative entities of the region may include support for inter-regional tour operators, branding of inter-regional (cross-border) tourism products, interaction in solving the problem of staffing in tourism, support and development of all forms of ecological and rural tourism, joint campaigns to popularize ecotourism, creating a tourist system monitoring, and exchanging information on border areas, development and interaction of regional and border information systems and creation of tourist information centers, exchange of staff in the tourism sector, ensuring interaction between educational institutions of states, the security of tourist trips.

\section{Conclusions}

Thus, the development of the Altai border territories is connected with the solution of a wide range of tasks for the protection of the natural and cultural heritage, the organization of tourism, and the search for ways of sustainable development of the territory. In the context of globalization, cross-border cooperation in the field of tourism is one of the most important elements of international cooperation. For the further development of tourism, it is necessary to comprehensively use border areas, ensure the accessibility of the territory by creating checkpoints and tourist infrastructure and developing cross-border tourist routes.

The authors have created maps to identify the features of the development of protected natural areas in the Altai border territories. The study done to identify the landscape diversity of protected areas and the analysis of nature 


\section{ENTREPRENEURSHIP AND SUSTAINABILITY ISSUES}

ISSN 2345-0282 (online) http://jssidoi.org/jesi/

2020 Volume 7 Number 4 (June)

http://doi.org/10.9770/jesi.2020.7.4(45)

conservation and tourism development activities made it possible to identify functional zones for the purpose of territorial tourism management. This can be a management tool for the sustainable development of border areas.

Based on the idea of the ecological frame of a territory, the authors have proposed a scheme of the eco-tourist frame. The security nuclei, a network of major tourist routes and centers, some places for creating border crossings were recommended.

The unique natural and cultural-historical tourist and recreational resources of the Altai and a relatively good ecological condition of the territory attract the attention of not only tourists, but also of many state, public and private organizations. In this regard, at the interstate and inter-regional levels, it is necessary to conclude an agreement aimed at sustainable nature management; to develop programs for sustainable development of the Altai border territory.

\section{References}

Altai-Sayan Ecoregion Conservation Strategy. Full Version. WWF, September 2012. 94 p.

Dunets, A. N.; Ivanova, V. N.; Poltarykhin, A. L. (2019) Cross-border tourism cooperation as a basis for sustainable development: a case study. Entrepreneurship and Sustainability Issues 6(4): 2207-2215. https://doi.org/10.9770/jesi.2019.6.4(45)

Hall, C. M. Tourism Planning: policies, process and relationships / C. M. Hall. -2nd ed. - Great Britain by Henry Ling Ltd, $2008,-302$ p.

Aleksandrova A. Yu. (2009). The role and influence of border, borderline and cross-border in the development of tourism. Sustainable tourism: strategic initiatives and partnerships. Ulan-Ude: Publishing House of the BSC SB RAS. Pp. 56-66.

Babin, V.G., Semenov Yu.M., Shitov A.V., Sukhova M.G., Kocheeva N.A., Zhuravleva O.V., Minaev A.I., Karanin A.V. (2011). Landscaping of the Ukok Quiet Zone Natural Park. Scientific journal geography and natural resources. No 3. Pp. 38-45.

Badenkov Yu.P. (2017). Life in the mountains. Natural and cultural diversity - a variety of development models. M.: GEOS, 479.

Badenkov, Yu. P. (2002). Transboundary mountainous territories in the context of globalization: Altai syndrome. Proceedings of the RAS. Geographical series. Number 3. Pp. 21-28

Bredikhin, A.V. (2004). Relief as a recreational condition and tourism resource. Herald Mosk. un-that. Ser. 5. Geography. No. 4. Pp. 23-28.

Vinokurov Yu.I., Krasnoyarova B.A., \& Surazakova S.P. (2006). Transboundary biosphere territory "Altai": ideas of conservation and development. Region: Economics and Sociology, No. 2, Vladimirov V.V. et al. (1986) District planning. M. Stroyizdat. - 325 p.

Garms, E.O., Sukhova M.G., \& Khromykh V.V. (2014) Identification of the functional suitability of natural-recreational areas of the transboundary Altai using geoinformation technologies World of Science, Culture, Education No. 1 (44) February 2014. Barnaul: “Concept". P. 381-383.

Evstropyeva, O. V. (2009) Cross-border tourism in the adjacent regions of Russia and Mongolia. Irkutsk: Publishing House of the Institute of Geography SB RAS. 143 p.

Kalikhman, T.P. (2007). Specially protected natural areas of the Baikal region. Proceedings of the RAS. A series of geographic, 3, 75-86.

Kolbovsky, E. Yu. (2008) Landscape Planning. M. Academy. 336 p.

Kolbovsky, E. Yu. (2006) Ecology of tourism and ecological tourism. M.: Academy. 256 p. 


\section{ENTREPRENEURSHIP AND SUSTAINABILITY ISSUES}

ISSN 2345-0282 (online) http://jssidoi.org/jesi/

2020 Volume 7 Number 4 (June)

http://doi.org/10.9770/jesi.2020.7.4(45)

Kolosov, V. A. (2010) Modern political geography and research on state borders. The theory of socio-economic geography: current status and development prospects. Rostov on the Don. Publishing House of the Southern Federal University. Pp. 56-65.

Korableva, O. N., Kalimullina, O. V., \& Mityakova, V. N. (2018). Innovation activity data processing and aggregation based on ontological modelling. Paper presented at the 2018 4th International Conference on Information Management, ICIM 2018, 1-4. doi:10.1109/INFOMAN.2018.8392659

Krasnoyarova B.A. (2010) Features and problems of cooperation between Altai and Mongolia. Cross-border and cross-border territories of Asian Russia and neighboring countries (problems and prerequisites for sustainable development). Novosibirsk: Publishing House of the SB RAS, 394-404

Mironenko N.S., \& Bochvarova M. (1986). Recreational systems. M. Publishing House of Moscow State University. 136 p.

Polyakova, A., Kolmakov, V., \& Yamova, O. (2019). Regional competitiveness response to innovation changes: Issues of evaluation. Journal of Urban and Regional Analysis, 11(2), 159-172. https://doi.org/10.37043/JURA.2019.11.2.3

Pomorov, S. B. (2008). Recreation and tourism in the mountains and foothills of Altai. Architectural and urban organization of recreation facilities. Barnaul. Publishing House of Altai State Technical University. 167 p.

Rodoman, B. B. (2002). Polarized Biosphere. Smolensk. Oikumena, P. 336

Samoilova, G.S. (2000) Landscape structure of the Altai-Khangae-Sayan ecoregion. Mountains and man: anthropogenic transformation of mountain geosystems. Novosibirsk Publishing House of the SB RAS. Pp. 111-112.

Sharafutdinov, R. I., Akhmetshin, E. M., Gerasimov, V. O., Shpakova, R. N., \& Mikhailova, M. V. (2019). Inclusive growth: A dataset on key and institutional foundations for inclusive development of Russian regions. Data in Brief, 23. https://doi.org/10.1016/j.dib.2019.103864

Singgalen, Y.A., Sasongko, G., Wiloso, P.G. 2019. Community participation in regional tourism development: a case study in North Halmahera Regency - Indonesia. Insights into Regional Development, 1(4), 318-332. https://doi.org/10.9770/ird.2019.1.4(3)

Stoyashcheva, H. B. (2007). Ecological framework of the territory and optimization of nature management in the south of Western Siberia (on the example of the Altai region). -Novosibirsk: Publishing House of the SB RAS. 140 p.

Suprunenko, Yu.P. (2003). Mountains are called ... (Mining and recreational nature use). - M. Trent. 386 p.

Chernova E.O. (2018). Allocation of economic and recreational zones in the Altai cross-border mountain region with a view to its sustainable development. Samara Luka: problems of regional and global ecology. T. 27, No. 3. Pp. 54-58.

Yashina T.V., \& Krykbaeva R.N. (2017). Big Altai Transboundary Biosphere Reserve: History of Creation and Strategies of Activity. Nature, culture and sustainable development of the Altai cross-border region. Gorno-Altaysk. BIC Gorno-Altai State University. Pp. $20-28$.

Yemelyanov, V. A., Yemelyanova, N. Y., Nedelkin, A. A., \& Zarudnaya, M. V. (2018). Neural network to diagnose lining condition. Paper presented at the IOP Conference Series: Materials Science and Engineering, 327(2) https://doi.org/10.1088/1757-899X/327/2/022107 


\section{ENTREPRENEURSHIP AND SUSTAINABILITY ISSUES}

ISSN 2345-0282 (online) http://jssidoi.org/jesi/

2020 Volume 7 Number 4 (June)

http://doi.org/10.9770/jesi.2020.7.4(45)

Alexandr Nikolaevich DUNETS, Doctor of Geographical Sciences, Professor, Dean of the Faculty of Geography of Altai State University. Research interest: sustainable development of tourism, ecology and environment, functional zoning, mountain region, tourism, the Altai-Sayan Mountains.

ORCID ID: https://orcid.org/0000-0002-3804-6800

Nataliia Andriivna GERASYMCHUK, Doctor of Sciences in Economics, Associate professor of Department of Economics, Management Faculty of Rzeszow University of Technology (Politechnika Rzeszowska). Poland, 35-959, Rzeszow, al. Powstancow Warszawy 12. Author specializes in the study of the economic and social efficiency of environmental protection measures; the role of small entrepreneurs in the local markets development. Currently engaged in teaching microeconomics and macroeconomics disciplines at the Faculty of Management of Politechnika Rzeszowska. Research interests: entrepreneurship, small enterprises development, resource saving, agro tourism, sustainable development.

ORCID ID: http://orcid.org/0000-0002-3931-5320

Vladimir Mikhailovich KURIKOV, Doctor of Sciences in Economics, Professor at the Institute of Digital Economy, Yugra State University, where he conducts research and supervises postgraduate research projects on economic sectors.

Research interests: socio-economic sustainable development of the Russian North; developing transport infrastructure of Russian oil and gas producing regions; increasing investment attraction of northern Russian oil and gas producing regions; economic diversification of northern Russian oil and gas producing regions; issues of the socio-economic development of the indigenous small-numbered peoples.

ORCID ID: http://orcid.org/0000-0002-1440-8870

Elena Evgenyevna NOEVA, Senior Lecturer, Department of Economics and Finance, Institute of Finance and Economics of NorthEastern Federal University named after M.K. Ammosov (NEFU).

Currently engaged in teaching economic and financial disciplines and research in the field of regional economics, sustainable development of territories, finance, entrepreneurship. Research interests: regional economics, sustainable development of territories, taxes, budget, entrepreneurship.

ORCID ID: $\underline{\text { http://orcid.org/0000-0003-3147-8050 }}$

Mariya Yurievna KUZNETSOVA, Senior Lecturer, Professor of the Department of propaedeutics of dental diseases of the Institute of Dentistry of Sechenov University. Currently engaged in teaching dentistry, as well as conducts research in the field of management, corporate reporting.

Research interests: management in dentistry, internal control systems, introduction of digital technologies.

ORCID: http://orcid.org/0000-0002-5488-8979

Rustem Adamovich SHICHIYAKH, Ph.D. in Economics, Associate professor, Department of Management, Kuban State Agrarian University named after I.T. Trubilin. Expert in the field of state regulation of agriculture and sustainable tourism development.

Research interests: state regulation of the economy, agriculture, sustainable development of tourism, rural areas, management, human capital, entrepreneurship

ORCID ID: http://orcid.org/0000-0002-5159-4350

Register for an ORCID ID:

https://orcid.org/register

Copyright (C) 2020 by author(s) and VsI Entrepreneurship and Sustainability Center

This work is licensed under the Creative Commons Attribution International License (CC BY).

http://creativecommons.org/licenses/by/4.0/

cC) (†) Open Access 